J. Amer. Soc. Hort. Sci. 118(1):151-157. 1993.

\title{
Shoot Organogenesis and Plant Regeneration from Cotyledons of Diploid, Triploid, and Tetraploid Watermelon
}

\author{
Michael E. Compton ${ }^{1}$ and D.J. Gray ${ }^{2}$ \\ Central Florida Research and Education Center, University of Florida, Institute of Food and \\ Agricultural Sciences, 5336 University Avenue, Leesburg, Florida 34748 \\ Additional index words. Citrullus lanatus, cucurbits, tissue culture
}

\begin{abstract}
Adventitious shoots were obtained from watermelon [ Citrullus lanatus (Thunb.) Matsun. \& Nakai] cotyledons incubated on a modified Murashige and Skoog medium containing BA. Initial experiments comparing the effects of BA $(0,5,10$, or $20 \mu \mathrm{M})$ and IA4 $(0,0.5$, or $5 \mu \mathrm{M})$ demonstrated that BA was required for adventitious shoot formation but its concentration in the medium was not critical. The addition of IAA to medium with BA increased callus production and inhibited shoot formation. However, the percentage of responding explants in the best treatment was $<30 \%$. Therefore, the manner in which cotyledon explants were prepared and seedling age at the time of explantation was examined to improve the organogenic response. The percentage of explants with shoots was improved by using explants that consisted of cotyledon bases $(43 \%)$ or cotyledons cut in half longitudinally (39\%). A lower percentage $(\mathbf{1 6 \%})$ of cotyledons cut longitudinally into four pieces produced shoots. Explants taken from the apical half of cotyledons failed to regenerate shoots. Shoot formation was improved further by using explants from young seedlings. The percentage of explants with shoots was $>90 \%$ for 'Minilee', $64 \%$ for $\mathrm{S86NE}$, and $50 \%$ for 'Jubilee II' when explants were prepared from 5-day-old seedlings. Explants from nongerminated embryos or seedlings germinated for 10, 15, or 20 days produced fewer shoots. The effect of several cytokinins on shoot organogenesis was then examined using the optimized protocol. The percentage of explants with shoots and the number of shoots per explant were about two to four times higher when 5 to $10 \mu \mathrm{M} \mathrm{BA}$ was used compared to the most effective kinetin $(20 \mu \mathrm{M})$ or thidiazuron $(0.1 \mu \mathrm{M})$ concentration. The percentage of explants with shoots and the number of shoots per explant were greater for diploid (57\% and 2.2, respectively) than for triploid (22\% and 0.6 , respectively) or tetraploid (20\% and 0.8, respectively) lines. Chemical names used: $N$-(phenylmethyl)-1 $H$-purin-6-amine (BA); 6-furfurylaminopurine (kinetin); $N$-phenyl- $N^{\prime}$-1,2,3-thiadiazol-5-ylurea (thidiazuron); $1 H$-indole3-acetic acid (IAA).
\end{abstract}

Potyviruses cause serious disease problems in commercial cucurbit plantings across the United States (Adlerz et al., 1983) and in other production areas of the world. Resistance to viruses such as zucchini yellow mosaic virus (ZYMV) exists in wild germplasm (Provvidenti, 1991); however, the introduction of this germplasm into commercial watermelon cultivars would result in the loss of favorable characteristics and require years of selective breeding to obtain acceptable virus resistant cultivars.

Biotechnology could be used as a means of introducing resistance to cucurbit potyviruses by inserting segments of viral DNA (e.g., sense, antisense, coat protein genes, etc.) into existing watermelon germplasm without altering the genetic identity of elite lines. This method has proven successful for obtaining transgenic plants resistant to alfalfa mosaic virus (Loesch-Fries et al., 1987; Turner et al., 1987; Van Dun et al., 1988), cucumber mosaic virus (Chee and Slightom, 1991; Cuozzo et al., 1988; Quemada et al., 1991), potato virus x and y (Hemenway et al., 1988; Hoekema et al., 1989; Kaniewski et al., 1990;

Received for publication 30 Mar. 1992. Accepted for publication 15 Aug. 1992. This is Florida Agr. Expt. Sta. J. Ser. no. R-02349. This work was supported by a grant from the State of Florida High Technology and Industry Council Applied Research Grants Program. Seeds were provided by Gary W. Elmstrom, Central Florida Research and Education Center, Institute of Food and Agricultural Sciences, Univ. of Florida, Leesburg, Fla. Use of trade names does not imply endorsement of the products named nor critism of similar products not mentioned. The cost of publishing this paper was defrayed in part by the payment of page charges. Under postal regulations, this paper therefore must be hereby marked advertisement solely to indicate this fact.

'Postdoctorate Research Assistant. To whom reprint requests should be addressed.

${ }^{2}$ Associate Professor.
Lawson et al., 1990), tobacco mosaicvirus (Nelson et al., 1988; Powell-Abel et al., 1986), tobacco streak virus (Van Dun et al., 1988) and tobacco rattle virus (Van Dun and Bol, 1988). However, an efficient in vitro plant regeneration system must be in place before such techniques can be employed.

Watermelon plants have been obtained through micropropagation of shoot tips (Anghel and Rosu, 1985; Barnes, 1979; Gray and Elmstrom, 1988), somatic embryogenesis from cotyledons of immature embryos (Compton and Gray, 1993), and adventitious shoot regeneration from cotyledon pieces (Anghel and Rosu, 1985; Dong and Jia, 1991; Srivastava et al., 1989). Genetic transformation of shoot tips has been successful in maize (Zea mays L.) (Gould et al., 1991); however, chimera production and low level gene expression are common problems. Although somatic embryogenesis was recently reported for watermelon, its use for genetic transformation is currently limited because of a low frequency of response. Adventitious shoot regeneration systems have been demonstrated as useful for obtaining genetically transformed plants (Horsch et al., 1985; McCormick et al., 1986), but reports of shoot regeneration from watermelon cotyledons are conflicting (i.e., differences in optimum growth regulator concentrations and combinations, age of explants, conditions for rooting, and acclimatization) and may not be suitable for many commercial cultivars. Therefore, the objective of this study was to develop an efficient adventitious shoot regeneration protocol for diploid, triploid, and tetraploid watermelon.

Abbreviations: NAA, a-naphthaleneacetic acid; 2, 4-D,2,4-dichlorophenoxyacetic acid; PGR, plant growth regulators; ZYMV, Zucchini yellow mosaic virus. 


\section{Materials and Methods}

Explant preparation and culture conditions. Watermelon seeds were surface-disinfected for $30 \mathrm{~min}$ in $2.5 \% \mathrm{NaClO}$ plus one drop $(100 \mathrm{ml})$ Triton $\mathrm{X}-100$, rinsed five times with sterile-distilled water, and soaked overnight (maximum $15 \mathrm{~h}$ ) in steriledistilled water in darkness. Embryos were extracted by removing the seedcoat and surface-disinfected for $10 \mathrm{~min}(20 \mathrm{~min}$ for 'Jubilee II') in $0.75 \% \mathrm{NaClO}$ plus one drop (per $100 \mathrm{ml}$ ) Triton $\mathrm{X}-100$ before six sterile-distilled water rinses. Embryos (nine per box) were germinated in Magenta $\mathrm{GA}_{7}$ vessels containing $50 \mathrm{ml}$ of MS salts (Murashige and Skoog, 1962) supplemented with (per liter) $20 \mathrm{~g}$ sucrose, $100 \mathrm{mg}$ myo-inositol, $2 \mathrm{mg}$ glycine, $0.5 \mathrm{mg}$ each of pyridoxine $\mathrm{HCl}$ and nicotinic acid, and $0.1 \mathrm{mg}$ thiamine $\mathrm{HCl}$. The $\mathrm{pH}$ of all media was adjusted to 5.7 before the addition of $7 \mathrm{~g}$ T.C. agar/liter (JRH Biosciences, Lenexa, Kan.) and autoclaving.

Unless otherwise stated, explants consisted of cotyledons from 5-day-old seedlings excised 1 to $2 \mathrm{~mm}$ above the point of attachment to the hypocotyl. The cotyledon margins $(1 \mathrm{~mm})$ were removed and the explants cultured abaxial side down on autoclaved medium containing test levels of growth regulators $(25$ $\mathrm{ml}$ per $100 \times 15 \mathrm{~mm}$ petri plate) for 6 weeks under a $16 \mathrm{~h}$ photoperiod (30 to $50 \mu \mathrm{mol} \cdot \mathrm{m}^{-2} \cdot \mathrm{s}^{-1}$ from cool-white fluorescent lamps) at $25 \mathrm{C}$. Plant growth regulators (PGRs) were prepared fresh at the time of media preparation. Explants were subcultured to fresh medium of the same composition at 3-week intervals. A minimum of three plates were cultured per treatment with five explants per plate. All experiments were conducted twice. Data recorded at 6 weeks included the number of explants with shoots and the number of shoots per explant. Statistical analysis was conducted using the GLM procedure of the Statistical Analysis System (SAS Institute, 1988). Percentage data were analyzed using the Catmod procedure (SAS Institute, 1988), and data sets that contained a large number of zeros were transformed using the square root transformation [(y $+0.5)^{1 / 2} ;$ Zar, 1984] before GLM analysis.

Effect of BA and IAA on shoot organogenesis. The effect of BA and IAA on adventitious shoot organogenesis was examined using cotyledons from 'Jubilee II', S86NE (a small-seeded breeding line of 'Dixielee'), and SP-90-1 (a tetraploid breeding line) seedlings. Cotyledons were removed from green seedlings before cotyledon expansion had occurred. This stage was determined by Srivastava et al. (1989) to be ideal for shoot organogenesis and occurred 5 or 10 days after placing 'Jubilee II' and SP-90-1, and S86NE embryos, respectively, on germination medium. All cotyledons were cut in half cross-wise and incubated on MS medium as above but with $30 \mathrm{~g}$ sucrose/liter, BA at $0,5,10$, or $20 \mu \mathrm{M}$ combined with IAA at $0,0.5$, or $5 \mu \mathrm{M}$.

Effect of explant type. Cotyledons from 5-day-old 'Jubilee II' or lo-day-old S86NE seedlings were cut cross-wise with the apical and basal halves cultured separately, or cut longitudinally into two or four strips. All explants were incubated on medium with $10 \mu \mathrm{M}$ BA for six weeks.

Effect of seedling age. The effect of seedling age on shoot organogenesis was examined by incubating 'Jubilee II', 'Minilee', and S86NE cotyledons from nongerminated embryos or seedlings germinated for $5,10,15$, or 20 days. All cotyledons were cut in half longitudinally and incubated on medium with $10 \mu \mathrm{M}$ BA for 6 weeks.

Effect of cytokinin type and concentration. 'Minilee' cotyledons were cut longitudinally into two pieces and incubated on medium supplemented with either BA or kinetin, each at 0,5 ,
10,20 , or $40 \mu \mathrm{M}$, or thidiazuron (TDZ) at $0,0.1,1,5$, or 10 $\mu \mathrm{M}$ for 6 weeks.

Shoot organogenesis from cotyledons of diploid, triploid and tetraploid watermelon. The ability of cotyledon explants from 11 diploid ('Allsweet', 'Bush Jubilee', 'Charlee', 'Charleston Gray', 'Crimson Sweet', 'Dixielee', 'Jubilee II', 'Mickylee', 'Minilee', 'Royal Sweet', and 'Sangria'), three triploid (CFREC 89-4, 'Jack of Hearts' and 'King of Hearts'), and three tetraploid (SP-90-1, SP-90-2, and SP-90-4) watermelon genotypes to regenerate adventitious shoots using the optimized protocol was examined. Explants from 5-day-old seedlings were cut longitudinally into two pieces and incubated on medium with 5, 10, or $20 \mu \mathrm{M}$ BA for 6 weeks.

Rooting and acclimatization of regenerated shoots. Explants with shoots were transferred to medium with $20 \mathrm{~g}$ sucrose/liter but without PGRs. After 3 weeks, adventitious shoots (0.5 to 3 $\mathrm{cm}$ ) were excised and transferred to rooting medium (MS as above, but with $20 \mathrm{~g}$ sucrose/liter and $0.1 \mu \mathrm{M} \mathrm{NAA}$ ) for 2 weeks. Plants were transplanted to cell packs $(4.0 \times 5.5 \mathrm{~cm}$ with 72 cells/flat $)$ or plug trays $(3.3 \times 5.1 \mathrm{~cm}$ with 72 plugs/ tray) filled with 1 ProMix BX: 1 coarse vermiculite, covered with a clear plastic lid, and grown under the same conditions as tissue cultures. After 7 days, the plants were acclimatized to ambient humidity levels by gradually removing the lid over 2 to 3 days. Acclimatized plants were moved to the greenhouse 14 days after transfer to soil and incubated under natural light levels and photoperiod.

\section{Results and Discussion}

Effect of BA and IAA on shoot organogenesis. The ability of cotyledon explants from the three genotypes to form shoots depended on the presence of BA in the medium. BA was required to promote shoot organogenesis, but its concentration in the medium did not significantly alter the percentage of 'Jubilee II' and S86NE explants with shoots (Fig. 1A) or the number of shoots per explant (data not shown). In contrast, cotyledon explants of SP-90-1 only formed shoots when cultured on medium with $20 \mu \mathrm{M}$ BA (Fig. 1A).

Adding IAA to the medium dramatically inhibited shoot organogenesis for all three genotypes tested. The percentage of 'Jubilee II' and S86NE explants with shoots (Fig. 1B) and the number of shoots per explant were reduced by $50 \%$ to $63 \%$ and $50 \%$ to $62 \%$, respectively, when IAA was added to medium with or without BA. Shoot formation was completely suppressed when SP-90-1 cotyledons were incubated on medium containing IAA.

These results are similar to the findings of Srivastava et al. (1989) who reported that shoot regeneration from cotyledons of the watermelon cultivar 'Melitopolski' was best on MS medium supplemented with BA $(5 \mu \mathrm{M})$ and inhibited by adding either 0.25 to $1 \mu \mathrm{M}$ of NAA or IAA. However, they failed to report the percentage of explants with shoots or the number of shoots per explant, making it difficult to determine the best medium for shoot organogenesis.

Effect of explant type. Shoot formation was best among explants made up of either cotyledon bases or cotyledons cut in half longitudinally (Table 1). A lower percentage of cotyledons cut longitudinally into four pieces produced shoots and explants from the apical half of cotyledons failed to regenerate shoots. Although there was no significant difference in the percentage of explants with shoots or the number of shoots per explant between explants comprised of cotyledon bases and cotyledons 



Fig. 1. Effect of (A) BA (data were average over all IAA concentrations) and (B) IAA (data were averaged over all BA concentrations) on the percentage of 'Jubilee II', S86NE, and SP-90-1 explants with shoots. Spikes represent the SE.

Table 1. Effect of explant dissection method on the percentage of explants with shoots and the number of shoots per explant. ${ }^{z}$

\begin{tabular}{lcccc}
\hline \hline $\begin{array}{l}\text { Explant dissection } \\
\text { method }\end{array}$ & $\begin{array}{c}\text { No. of } \\
\text { explants }\end{array}$ & $\begin{array}{c}\text { Explants with } \\
\text { shoots (\%) }\end{array}$ & $\begin{array}{c}\text { No. of } \\
\text { shoots per } \\
\text { explant }\end{array}$ & $\begin{array}{c}\text { No. of } \\
\text { shoots per } \\
\text { seedlingy }\end{array}$ \\
\hline Basal half & 91 & $43 \pm 7.3$ & $2.0 \pm 0.3$ & 4.0 \\
Apical half & 95 & 0.0 & 0.0 & 0.0 \\
$\begin{array}{l}\text { Longitudinal halves } \\
\text { Longitudinal }\end{array}$ & 92 & $39 \pm 6.9$ & $1.9 \pm 0.3$ & 7.6 \\
$\quad$ fourths & 90 & $16 \pm 4.1$ & $0.6 \pm 0.2$ & 4.8 \\
\hline
\end{tabular}

z'Jubilee II' and S86NE cotyledon explants were incubated on medium with $10 \mu \mathrm{M}$ BA.

yobtained by multiplying the number of shoots per explant by the number of explants that were obtained from each seedling.

xPortion of the cotyledon proximal to the seedling hypocotyl.

wPortion of the cotyledon distal to the seedling hypocotyl.

\pm values represent the SE.

cut in half longitudinally, almost twice as many shoots were produced per seedling when the latter explant type was used (Table 1).
Visual observations of explants consisting of longitudinal halves of cotyledons determined that shoots originated solely from the base of the cotyledon. This pattern indicates that cells competent for shoot formation are restricted to this site. Similar observations have been reported for Cucumis sativus L. (Gambley and Dodd, 1990) and Cucumis melo L. (Leshem, 1989). In tomato ( Lycopersicon esculentum Mill.), shoot formation occurred predominantly at, but was not restricted to, the base of cotyledon explants (Monacelli et al., 1988).

Effect of seedling age. The percentage of 'Minilee' and 'Jubilee II' explants from 5-day-old seedlings that formed shoots was higher than that from explants from nongerminated embryos and 10-, 15-, and 20-day-old seedlings (Fig. 2A). For S86NE, the percentage of explants with shoots was higher for explants from 5- (64\%) or 10-day-old (54\%) seedlings than for explants from nongerminated embryos or from 15- and 20-day-old seedlings. The number of shoots per explant was highest for all three genotypes when cotyledon explants from 5-day-old seedlings were used (Fig. 2B). Leaves from 21-day-old seedlings failed to regenerate shoots (data not shown).

Although watermelon cells were competent to form shoots at all the explant ages tested, more 'Minilee', 'Jubilee II', and S86NE cells became competent after 5 or 5 to 10 days, respectively, on germination medium. Similar results were obtained

\section{Explants with shoots (\%)}

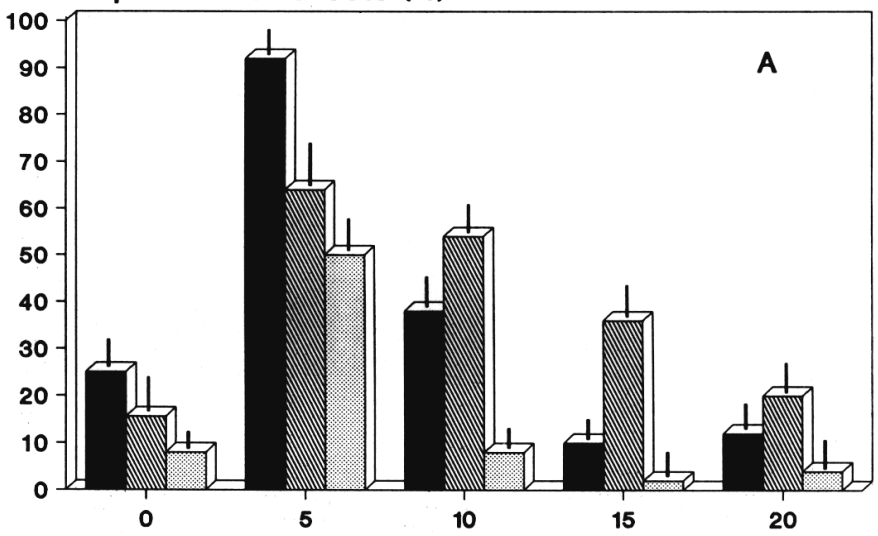

Number of shoots per explant

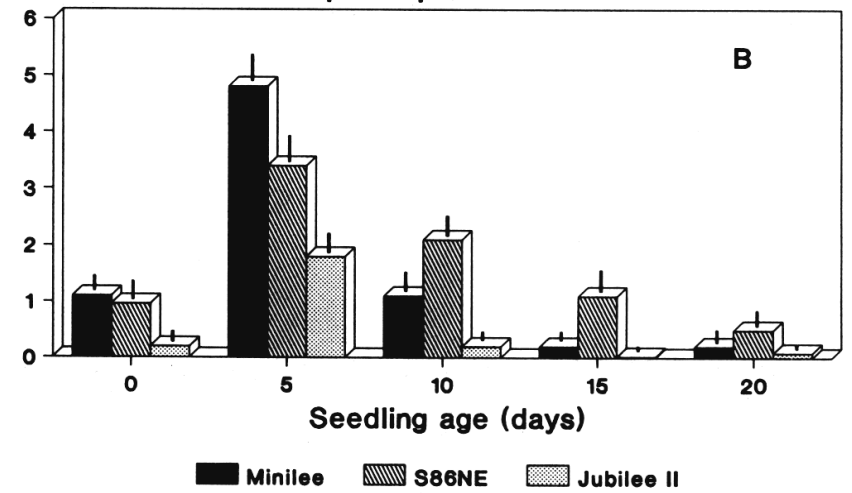

Fig. 2. Effect of seedling age on (A) the percentage of explants with shoots and (B) the number of shoots per explant after 6 weeks of culture on medium with $10 \mu \mathrm{M}$ BA. 'Jubilee II', 'Minilee', and S86NE cotyledon explants were taken directly from nongerminated embryos ( 0 ) or from seedlings germinated for $5,10,15$, or 20 days on medium without PGRs. Spikes represent the SE. 
for cotyledon explants of muskmelon (Cucumis melo L. 'Hales's Best Jumbo'). Niedz et al. (1989) observed that shoot formation was better for cotyledon explants from 4- and 7-day-old seedlings than for cotyledons or leaves from 18-day-old seedlings. Leaf explants of Convolvulus arvensis L. required a minimum of 4 days on callus induction or 14 days on shoot induction medium before becoming "determined" for shoot regeneration (Christianson and Warnick, 1983).

Effect of cytokinin type and concentration. The percentage of explants with shoots (Fig. 3A) and the number of shoots per explant (Fig. 3B) were highest when medium was supplemented with BA $(5$ and $10 \mu \mathrm{M})$ compared to the best kinetin $(20 \mu \mathrm{M})$ or thidiazuron $(0.1 \mu \mathrm{M})$ concentration. Many of the shoots that originated from explants cultured on medium with 20 or $40 \mu \mathrm{M}$ $\mathrm{BA}$, or TDZ, were abnormal (thick and stunted) and/or vitrified. Shoots originating from explants incubated on medium with kinetin were highly elongated and easiest to handle; however, stem elongation occurred at the expense of adventitious shoot formation. We have observed similar results for watermelon shoot tip cultures (data not shown).

Our results differ from those of Dong and Jia (1991) stating that shoot regeneration of watermelon cotyledons was best on



Number of shoots per explant

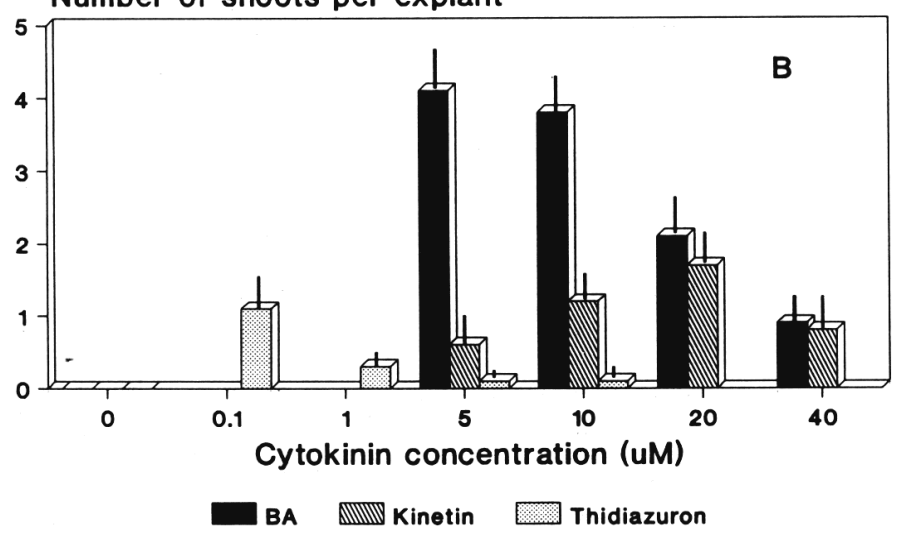

Fig. 3. Effect of BA, kinetin (each at $0,5,10,20$, and $40 \mu \mathrm{M}$ ) and thidiazuron $(0,0.1,1,5$, and $10 \mu \mathrm{M})$ on (A) the percentage of explants with shoots and (B) the number of shoots per explant. 'Minilee' cotyledon explants were incubated on test media for 6 weeks. Spikes represent the SE.
MS medium with BA $(22.2 \mu \mathrm{M})$ and IAA $(2.85 \mu \mathrm{M})$. The difference in results may be related to the genotypes tested. In a direct comparison of our regeneration protocol with theirs, we observed that about twice as many 'Allsweet', 'Crimson Sweet', 'Jubilee II', 'Minilee', CFREC89-4, SP-90-1, and SP-90-4 cotyledon explants produced shoots with about three times the number of shoots per explant when our protocol was used (data not shown).

Anghel and Rosu (1985) reported that shoot formation occurred when cotyledon explants of diploid and tetraploid watermelon were incubated on MS medium with 4.4 to $10.5 \mu \mathrm{M}$ BA either alone or with 0.1 to $0.45 \mu \mathrm{m} 2,4-\mathrm{D}, 0.1 \mu \mathrm{M}$ IAA, or $0.98 \mu \mathrm{M} 1 \mathrm{H}$-indole-3-butyric acid (IBA). However, they failed to present data on the percentage of explants with shoots or the number of shoots per explant.

Shoot organogenesis from cotyledons of diploid, triploid, and tetraploid watermelon. The percentage of explants with shoots and the number of shoots per explant were higher for diploid watermelon lines (57\% and 2.2, respectively) than for triploid ( $22 \%$ and 0.6 , respectively) or tetraploid (20\% and 0.8 , respectively) lines. Shoot formation was best (based on a mean response of 70\%) for 'Dixielee', 'Minilee', 'Mickylee', and 'Crimson Sweet' (Table 2). A significant interaction between the BA concentration in the medium and genotype was observed for the percentage of 'Bush Jubilee', 'Charleston Gray', 'Mickylee', and SP-90-4 explants with shoots and the number of shoots per explant. Shoot formation was best for 'Bush Jubilee' and 'Charleston Gray' when explants were incubated on medium with $5 \mu \mathrm{M}$ BA, whereas more 'Mickylee' and SP-90-4 explants produced shoots when placed on medium with $10 \mu \mathrm{M}$ BA (Table 2 ). Although the BA concentration did not significantly affect the percentage of 'Minilee' explants that produced shoots, the number of shoots per explant was higher when $10 \mu \mathrm{M}$ BA was used. No difference between 5 and $10 \mu \mathrm{M}$ BA was observed for the remaining genotypes examined. Shoot production was poor on explants of the triploid and tetraploid genotypes tested regardless of the BA concentration. Incubating explants of triploid and tetraploid genotypes on medium with $20 \mu \mathrm{M}$ BA failed to improve the organogenic response (data not shown). The percentage of shoots that produced roots ranged from 0\% (SP90-2) to $100 \%$ (CFREC 89-4 and SP-90-1) with a mean rooting percentage of $71 \%$ across all genotypes and BA concentrations. There was no effect of ploidy level or BA concentration on the ability of regenerated shoots to form roots. The percentage of plants acclimatized to the greenhouse ranged from $50 \%$ (CFREC89-4) to $100 \%$ ('Mickylee') with an overall mean of $72 \%$.

Our results demonstrate that all watermelon genotypes tested were competent for shoot organogenesis, but to varying degrees, which is typical of tissue cultures of many plant species (Compton and Veilleux, 1991; Dong and Jia, 1991; Fish and Jones, 1988; Frankenberger et al., 1981a, 1981b; McCormick et al., 1986; Oridate et al., 1992). Competence of the more recalcitrant watermelon genotypes may be improved by modifying the existing protocol (i.e., age of cotyledons at the time of excisson, other PGR combinations, etc.). Christianson and Wamick (1985) promoted shoot formation in previously recalcitrant $C$. arvensis genotypes (those only capable of rhizogenesis) by culturing explants on root induction medium for 3 to 5 days before transfer to shoot induction medium. The opposite occurred when genotypes recalcitrant for root formation were cultured on shoot induction medium before incubation on root induction medium. However, this may not be the case for watermelon polyploids. 
Table 2. Percentage of explants with shoots, number of shoots per explant, and percentage of rooted microshoots obtained from shoots regenerated from cotyledons of diploid, triploid, and tetraploid watermelon genotypes. ${ }^{z}$

\begin{tabular}{|c|c|c|c|c|c|c|}
\hline Genotype & $\begin{array}{c}\text { Ploidy } \\
\text { level }\end{array}$ & $\begin{array}{c}\text { BA } \\
\text { concn } \\
(\mu \mathrm{M})\end{array}$ & $\begin{array}{r}\text { Expla } \\
\text { with sh } \\
(\%) \\
\end{array}$ & $\begin{array}{l}\text { ints } \\
\text { noots } \\
\end{array}$ & $\begin{array}{l}\text { No. of } \\
\text { shoots per } \\
\text { explant }\end{array}$ & $\begin{array}{l}\text { Rooted } \\
\text { microshoots } \\
(\%)\end{array}$ \\
\hline \multirow[t]{2}{*}{ Allsweet } & $2 n$ & 5 & $40 \pm$ & 8.9 & $1.5 \pm 0.4$ & $40 \pm 15.5$ \\
\hline & & 10 & $50 \pm$ & 9.1 & $1.6 \pm 0.4$ & $47 \pm 12.9$ \\
\hline \multirow[t]{2}{*}{ Bush Jubilee } & $2 n$ & 5 & $73 \pm 1$ & 11.4 & $3.5 \pm 0.7$ & $94 \pm 5.7$ \\
\hline & & 10 & $47 \pm 1$ & 12.9 & $2.1 \pm 0.7$ & $91 \pm 8.7$ \\
\hline \multirow[t]{2}{*}{ Charlee } & $2 n$ & 5 & $37 \pm$ & 8.8 & $0.8 \pm 0.2$ & $87 \pm 11.7$ \\
\hline & & 10 & $40 \pm$ & 8.9 & $1.1 \pm 0.3$ & $77 \pm 11.7$ \\
\hline \multirow[t]{2}{*}{ Charleston Gray } & $2 n$ & 5 & $77 \pm$ & 7.7 & $2.8 \pm 0.5$ & $56 \pm 16.6$ \\
\hline & & 10 & $53 \pm$ & 9.1 & $1.6 \pm 0.3$ & $89 \pm 10.5$ \\
\hline \multirow[t]{2}{*}{ Crimson Sweet } & $2 n$ & 5 & $76 \pm$ & 8.5 & $2.8 \pm 0.4$ & $82 \pm 7.2$ \\
\hline & & 10 & $83 \pm$ & 7.0 & $3.2 \pm 0.4$ & $48 \pm 10.4$ \\
\hline \multirow[t]{2}{*}{ Dixielee } & $2 n$ & 5 & $87 \pm$ & 6.2 & $3.6 \pm 0.5$ & $78 \pm 2.9$ \\
\hline & & 10 & $93 \pm$ & 4.6 & $3.6 \pm 0.4$ & $\ldots y$ \\
\hline \multirow[t]{2}{*}{ Jubilee II } & $2 n$ & 5 & $67 \pm$ & 8.6 & $1.5 \pm 0.3$ & $82 \pm 8.2$ \\
\hline & & 10 & $52 \pm$ & 9.9 & $1.3 \pm 0.3$ & $57 \pm 18.7$ \\
\hline \multirow[t]{2}{*}{ Mickylee } & $2 n$ & 5 & $77 \pm$ & 7.7 & $3.4 \pm 0.5$ & $87 \pm 5.4$ \\
\hline & & 10 & $90 \pm$ & 5.5 & $4.2 \pm 0.5$ & $74 \pm 7.4$ \\
\hline \multirow[t]{2}{*}{ Minilee } & $2 n$ & 5 & $83 \pm$ & 6.8 & $3.6 \pm 0.4$ & $90 \pm 2.1$ \\
\hline & & 10 & $93 \pm$ & 4.6 & $4.6 \pm 0.4$ & $92 \pm 3.6$ \\
\hline \multirow[t]{2}{*}{ Royal Sweet } & $2 n$ & 5 & $50 \pm$ & 9.1 & $1.9 \pm 0.4$ & $54 \pm 15.0$ \\
\hline & & 10 & $47 \pm$ & 9.1 & $1.8 \pm 0.5$ & $62 \pm 9.9$ \\
\hline \multirow[t]{2}{*}{ Sangria } & $2 n$ & 5 & $33 \pm$ & 8.6 & $1.4 \pm 0.4$ & $71 \pm 17.1$ \\
\hline & & 10 & $23 \pm$ & 7.7 & $0.8 \pm 0.3$ &.$-- y$ \\
\hline \multirow[t]{2}{*}{ CFREC 89-4 } & $3 n$ & 5 & $28 \pm$ & 8.9 & $0.8 \pm 0.3$ & 100 \\
\hline & & 10 & $20 \pm$ & 8.0 & $0.8 \pm 0.4$ & $50 \pm 20.4$ \\
\hline \multirow[t]{2}{*}{ Jack of Hearts } & $3 n$ & 5 & $23 \pm$ & 7.7 & $0.5 \pm 0.2$ & $80 \pm 1.8$ \\
\hline & & 10 & $20 \pm$ & 7.3 & $0.7 \pm 0.3$ & $60 \pm 2.2$ \\
\hline \multirow[t]{2}{*}{ King of Hearts } & $3 n$ & 5 & $23 \pm$ & 7.7 & $0.6 \pm 0.2$ & $81 \pm 1.8$ \\
\hline & & 10 & $17 \pm$ & 6.8 & $0.5 \pm 0.2$ & $75 \pm 2.1$ \\
\hline \multirow[t]{2}{*}{ SP90-1 } & $4 n$ & 5 & $23 \pm$ & 7.7 & $1.0 \pm 0.4$ & $78 \pm 13.9$ \\
\hline & & 10 & $13 \pm$ & 6.2 & $0.5 \pm 0.3$ & 100 \\
\hline \multirow[t]{2}{*}{ SP90-2 } & $4 n$ & 5 & $17 \pm$ & 6.8 & $0.5 \pm 0.2$ & $43 \pm 18.7$ \\
\hline & & 10 & $20 \pm$ & 7.3 & $1.1 \pm 0.4$ & 0 \\
\hline \multirow[t]{2}{*}{ SP90-4 } & $4 n$ & 5 & $10 \pm$ & 5.5 & $0.2 \pm 0.2$ & $80 \pm 17.9$ \\
\hline & & 10 & $47 \pm$ & 9.1 & $1.3 \pm 0.4$ & $62 \pm 17.1$ \\
\hline
\end{tabular}

${ }^{z}$ The number of explants for each treatment ranged from 25 to 30 .

'Shoots became contaminated during incubation on rooting medium. \pm values represent the SE.

These plants, especially triploids, display many developmental abnormalities [e.g., small embryos with poorly developed cotyledons, poor embryo viability, and slow germination and seedling development (Kihara, 1951)] that may hamper the ability of cotyledon explants to form shoots.

Description of cultures and regenerated plants. Green meristematic protrusions, which resembled young shoot apices, were observed at the base of enlarged cotyledons 9 to 12 days after initiating explants on medium with BA (Fig. 4A). Meristems were observed 2 to 3 days earlier when explants were incubated on medium with $2020 \mu \mathrm{M} \mathrm{BA}$; however, shoots that grew from explants incubated on medium with 5 or $10 \mu \mathrm{M} \mathrm{BA}$ were of higher quality (i.e., elongated normally with fewer instances of vitrification).

Adventitious shoots were macroscopically visible (Fig. 4B) 4 to 6 weeks after cotyledon explants were placed on medium with BA. Transferring explants with shoots, regardless of BA concentration, to medium without BA encouraged shoot elongation (Fig. 5A). After 3 weeks on medium without BA, these shoots could be removed and rooted in vitro. Rooted plants were acclimatized in cell packs (Fig. 5B) and grown in the laboratory
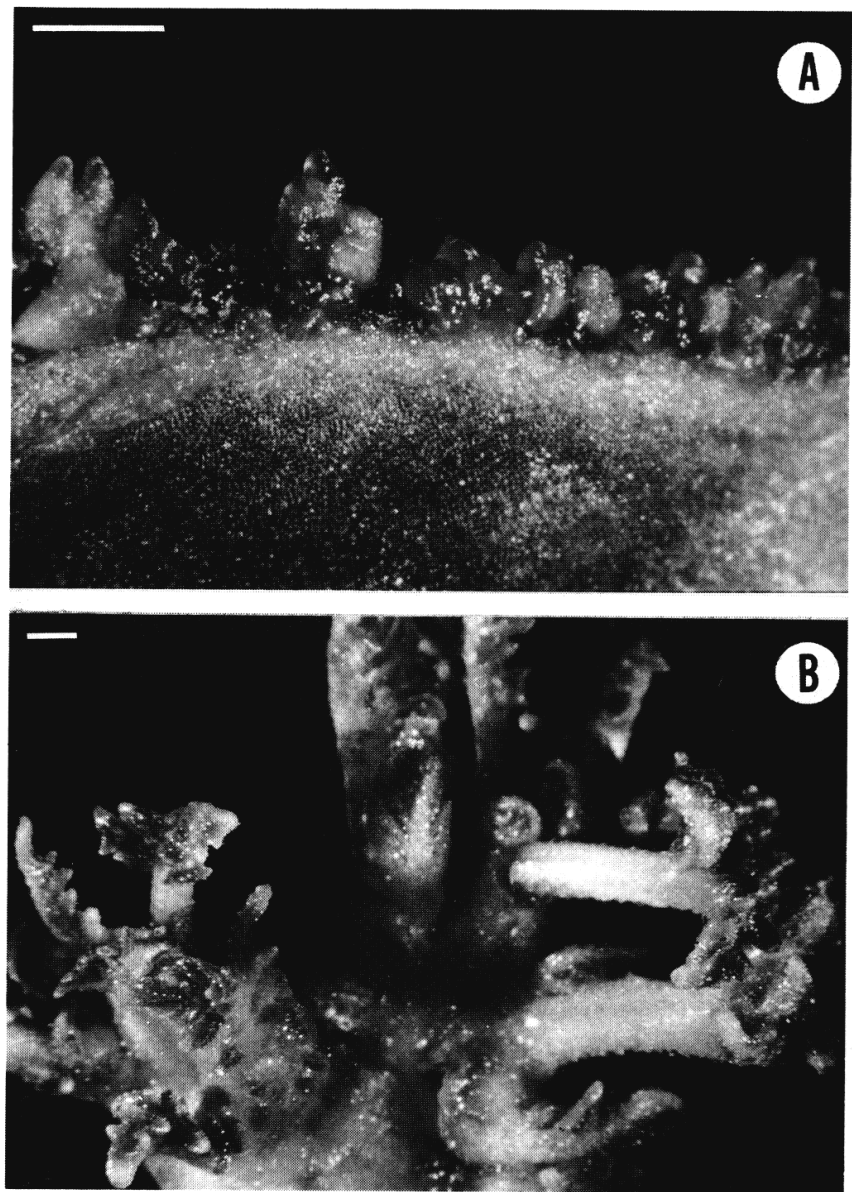

Fig. 4. Shoot development on watermelon cotyledon explants incubated on medium with $10 \mu \mathrm{M} \mathrm{BA}$. (A) Green meristematic protrusions were observed on the base of enlarged cotyledons 9 to 12 days after culture initiation. (B) Meristematic protrusions developed into 0.5 to $1 \mathrm{~cm}$ shoots 4 to 6 weeks after culture initiation; scale bar $=$ $1 \mathrm{~mm}$.

at ambient humidity levels for 14 days before transfer to the greenhouse where they were grown to maturity (Fig. 5C).

Plants produced using this procedure appeared uniform and true-to-type; however, some variants in leaf shape and ploidy (as determined by the number of chloroplasts per guard cell) were observed. About $90 \%$ of the regenerated plants that produced abnormal leaves in vitro developed normal leaf shape after acclimatization to ambient humidity levels. The occurrence of tetraploid regenerants was random and not associated with any one genotype. Tetraploid plants were obtained from 'Mickylee' (3/60), 'Dixielee' (2/21), 'Minilee' (1/52), 'Crimson Sweet' (1/34), and 'Royal Sweet' (1/21).

The regeneration of spontaneous tetraploids from diploid individuals would be undesirable if this system were to be used as a means of clonally propagating unique individuals; however, the system could be a useful tool if the goal was to generate tetraploids for seedless watermelon production. The occurrence of tetraploid regenerants may also be a desirable means of obtaining genetically improved triploid watermelon cultivars. Diploid tissue could be subjected to an amenable genetic transformation protocol and the resulting genetically transformed diploid and tetraploid plants could then be used as parents for the development of genetically superior seedless watermelon cultivars. 


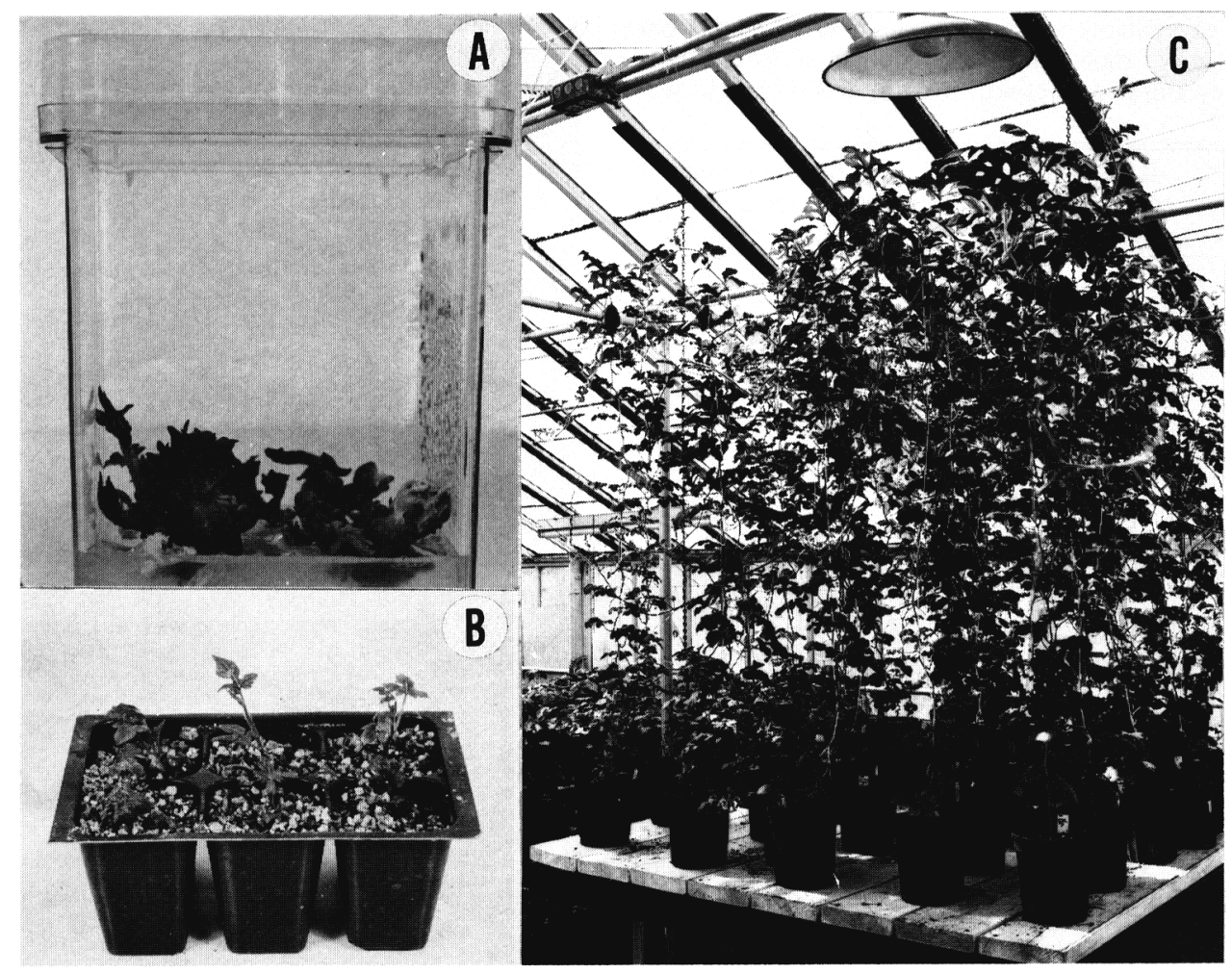

Fig. 5. (A) Explants with shoots transferred to Magenta GA, vessels containing medium without PGRs. (B) Rooted shoots transferred to cell packs containing 1 ProMix : 1 coarse vermiculite for acclimatization. (C) Acclimatized plants grown to maturity in the greenhouse.

\section{Literature Cited}

Adlerz, W.C., D.E. Purcifull, G.W. Simone, and E. Hiebert. 1983. Zucchini yellow mosaic virus: A pathogen of squash and other cucurbits in Florida. Proc. Fla. State Hort. Sci. 96:72-74.

Anghel, I. and A. Rosu. 1985. In vitro morphogenesis in diploid, triploid and tetraploid genotypes of watermelon- Citrullus lanatus (Thumb.) Mansf. Rev. Roum. Biol. Vega. 30:43-55.

Barnes, L.R. 1979. In vitro propagation of watermelon. Scientia Hort. 11:223-227.

Chee, P.P. and J.L. Slightom. 1991. Transfer and expression of cucumber mosaic virus coat protein gene in the genome of Cucumis sativus. J. Amer. Soc. Hort. Sci. 116:1098-1102.

Christianson, M.L. and D.A. Warnick. 1983. Competence and determination in the process of in vitro shoot organogenesis. Dev. Biol. 95:288-293.

Christianson, M.L. and D.A. Warnick. 1985. Temporal requirement for phytohormone balance in the control of organogenesis in vitro. Dev. Biol. 112:494-497.

Compton, M.E. and D.J. Gray. 1993. Somatic embryogenesis and plant regeneration from immature cotyledons of watermelon. Plant Cell Rep. (In press).

Compton, M.E. and R.E. Veilleux. 1991. Shoot, root and flower morphogenesis on tomato inflorescence explants. Plant Cell Tissue Organ Cult. 24:223-231.

Cuozzo, M., K.M. O’Connell, W. Kaniewski, R.-X. Fang, N.-H. Chua, and N.E. Turner. 1988. Viral protection in transgenic tobacco plants expressing the cucumber mosaic virus coat protein or its antisense RNA. Bio/technology 6:549-557.

Dong, J.-Z. and S.-R. Jia. 1991. High efficiency plant regeneration from cotyledons of watermelon (Citrullus vulgaris Schrad.). Plant Cell Rep. 9:559-562.

Fish, N. and M.G.K. Jones. 1988. A comparison of tissue culture response between related tetraploid and dihaploid $S$. tuberosum genotypes. Plant Cell Tissue Organ Cult. 15:201-210.
Frankenberger, E.A., P.M. Hasegawa, and E.C. Tigchelaar. 1981a. Influence of environment and developmental state on the shoot-forming capacity of tomato genotypes. Z. Pflanzenphysiol 102:221-232.

Frankenberger, E.A., P.M. Hasegawa, and E.C. Tigchelaar. 1981 b. Diallel analysis of shoot-forming capacity among selected tomato genotypes. Z. Pflanzenphysiol 102:233-242.

Gambley, R.L. and W.A. Dodd. 1990. An in vitro technique for the production de novo of multiple shoots in cotyledon explants of cucumber (Cucumis sativus L.). Plant Cell Tissue Organ Cult. 20:177183.

Gould, J., M. Devey; O. Hasegawa, E.C. Ulian, G. Peterson, and R.H. Smith. 1991. Transformation of Zea mays L. using Agrobacterium tumefaciens and the shoot apex. Plant Physiol. 95:426-434.

Gray, D.J. and G.W. Elmstrom. 1988. Novel process for the accelerated production of triploid seeds for seedless watermelon cultivars. U.S. Patent 5,007,198.

Hemenway, C., R.-X. Fang, W.K. Kaniewski, N.-H. Chua, and N.E. Turner. 1988. Analysis of the mechanism of protection in transgenic plants expressing the potato $\mathrm{X}$ coat protein or its antisense RNA. Embo J. 7:1273-1280.

Hoekema, A., M.J. Huisman, L. Molendkjk, P.J.M. van den Elzen, and B.J.C. Cornelissen. 1989. The genetic engineering of two commercial potato cultivars for resistance to potato virus X. Bio/technology 7:273-278

Horsch, R.B., J.E. Fry, N.L. Hoffmann, D. Eichholtz, S.G. Rogers, and R.T. Fraley. 1985. A simple and general method for transferring genes into plants. Science 227:1239-1231.

Kaniewski, W., C. Lawson, B. Sammons, L. Haley, J. Hart, X. Delannay, and N.E. Turner. 1990. Field resistance of transgenic Russet Burbank potato to effects of infection by potato virus $\mathrm{X}$ and potato virus Y. Bio/technology 8:750-754.

Kihara, H. 1951. Triploid watermelons. Proc. Amer. Soc. Hort. Sci. 58:217-230.

Lawson, C., W. Kaniewski, L. Haley, R. Rozman, C. Newell, P. 
Sanders, and N.E. Turner. 1990. Engineering resistance to mixed virus infection in a commercial potato cultivar: Resistance to potato virus $\mathrm{X}$ and potato virus $\mathrm{Y}$ in transgenic Russet Burbank. Bio/technology 8:127-134.

Leshem, B. 1989. Polarity and response regions for regeneration in the cultured melon cotyledon. J. Plant Physiol. 135:237-239.

Loesch-Fries, L.S., D. Merlo, T. Zinnen, L. Burhop, K. Hill, K. Krahn, N. Jarvis, S. Nelson, and E. Halk. 1987. Expression of alfalfa mosaic virus RNA4 in transgenic plants confers virus resistance. Embo J. 6:1845-1851.

McCormick, S., J. Niedermeyer, J. Fry, A. Barnason, R. Horsch, and R. Fraley. 1986. Leaf disc transformation of cultivated tomato (L. esculentum) using Agrobactetium tumefaciens. Plant Cell Rep. 5:8184.

Monacelli, B., M.M. Altamura, G. Pasqua, M.G. Biasini, and F. Sala. 1988. The histogenesis of somaclones from tomato (Lycopersicon esculentum Mill.) cotyledons. Protoplasma 142:156-163.

Murashige, T. and F. Skoog. 1962. A revised medium for rapid growth and bioassays with tobacco tissue cultures. Physiol. Plant. 15:473-497.

Nelson, R.S., S.M. McCormick, X. Delannay, P. Dubé J. Layton, E.J. Anderson, M. Kaniewska, R.K. Proksch, R.B. Horsch, S.G. Rogers, R.T. Fraley, and R.N. Beachy. 1988. Virus tolerance, plant growth, and field performance of transgenic tomato plants expressing coat protein from tobacco mosaic virus. Bio/technology 6:403-409.

Niedz, R.P., S.S. Smith, K.B. Dunbar, C.T. Stephens, and H.H. Murakishi. 1989. Factors influencing shoot regeneration from cotyledonary explants of Cucumis melo. Plant Cell Tissue Organ Cult. 18:313-319.

Oridate, T., H. Atsumi, S. Ito, and H. Araki. 1992. Genetic differences in somatic embryogenesis from seeds in melon (Cucumis melo L.). Plant Cell Tissue Organ Cult. 29:27-30.
Powell-Abel, P., R.S. Nelson, B. De, N. Hoffman, S.G. Rogers, R.T. Fraley, and R.N. Beachy. 1986. Delay of disease development in transgenic plants that express the tobacco mosaic virus coat protein gene. Science 232:738-743.

Prowidenti, R. 1991. Inheritance of resistance to the Florida strain of zucchini yellow mosaic virus in watermelon. HortScience 26:407408.

Quemada, H.D., D. Gonsalves, and J.L. Slightom. 1991. Expression of coat protein gene from cucumber mosaic virus strain $\mathrm{c}$ in tobacco: Protection against infections by CMV strains transmitted mechanically by aphids. Phytopathology 81:794-802.

SAS Institute. SAS/STAT user's guide. 1988. Release 6.03. SAS Institute, Cary, N.C.

Srivastava, D.R., V.M. Andrianov, and E.S. Piruzian. 1989. Tissue culture and plant regeneration of watermelon ( Citrullus vulgaris Schrad. cv. Melitopolski). Plant Cell Rep. 83300-302.

Turner, NE., K.M. O'Connell, R.N. Nelson, P.R. Sanders, R.N. Beachy, R.T. Fraley, and D.M. Shah. 1987. Expression of alfalfa mosaic virus coat protein gene confers cross-protection in transgenic tobacco and tomato plants. Embo J. 6:1181-1188.

Van Dun, C.M.P. and J.F. Bol. 1988. Transgenic tobacco plants accumulating tobacco rattle virus coat protein resist infection with tobacco rattle virus and pea early browning virus. Virology 167:649652.

Van Dun, C.M.P., B. Qverduin, L. van Vloten-Doting, and J.F. Bol. 1988. Transgenic tobacco expressing tobacco streak virus or mutated alfalfa mosaic virus coat protein does not cross protect against alfalfa mosaic virus infection. Virology 164:383-389.

Zar, J.H. 1984. Biostatistical analysis. 2nd ed. Prentice Hall, Englewood Cliffs, N.J. 